\title{
Evaluation of the Effects of Multiple Transfusions on Lipid Peroxidation in Preterm Infants
}

\author{
Zeynep Alp Unkar ${ }^{1 *}$, Asli Memisoglu ${ }^{1}$, Hulyaselva Bilgen ${ }^{1}$, Ali Yaman² ${ }^{2}$ Hülya Özdemir ${ }^{1}$, Goncagül Haklar ${ }^{2}$ and \\ Eren Ozek ${ }^{1}$ \\ ${ }^{1}$ Department of Pediatrics, Division of Neonatology, Marmara University Faculty of Medicine, Turkey \\ ${ }^{2}$ Department of Pediatrics, Department of Biochemistry, Marmara University Faculty of Medicine, Turkey
}

Submission: October 03, 2016; Published: December 01, 2016

*Corresponding author: Zeynep Alp Unkar, Department of Pediatrics, Division of Neonatology, Marmara University Faculty of Medicine, Turkey, Tel: 905369 876657; Email: md.zeynepalp@gmail.com

\begin{abstract}
Aim: Preterm infants commonly receive at least one packed red blood cell transfusion during their stay in the neonatal intensive care unit and even though the complications related to prematurity are multifactorial, especially bronchopulmonary dysplasia, necrotizing enterocolitis and intraventricular hemorrhage have been shown to be independently related with red blood cell transfusions. This study aims to determine the extent of lipid peroxidation in preterm babies after multiple transfusions, and to figure out acut-off value of ferritin to start or withhold iron prophylaxis in transfused babies.

Methods: Serum malondialdehyde and ferritin levels of 23 preterm babies (born earlier than 35th gestational week) were measured and the relation between total number of red blood cell transfusions, malondialdehyde and ferritin levels were assessed.

Results: The relations between the transfusion numbers and ferritin levels; and, ferritin and malondialdehyde levels were statistically significant. Another noteworthy finding was that the increase in serum malondialdehyde levels was significantly higher in infants with serum ferritin levels $>450 \mathrm{ng} / \mathrm{mL}$.
\end{abstract}

Conclusion: It is important to monitor serum iron status and lipid peroxidation in preterm babies who were multiply-transfused. Ferritin and malondialdehyde levels can be used for this monitorization.

Keywords: Red blood cell transfusion; Malondialdehyde; Ferritin; Preterm

\section{Introduction}

Preterm infants, especially those smaller than 29 weeks of gestation and birth weight less than $1000 \mathrm{gr}$, often receive at least one red blood cell (RBC) transfusion during their stay in the neonatal intensive care unit (NICU) mostly for the treatment of anemia of prematurity [1-3]. The anemia of prematurity is caused by multiple factors; the most common being blood loss due to clinical testing and diminished bone marrow production caused by decreased erythropoietin levels and low iron stores $[1,4]$. Many studies show correlations between transfusions and complications of prematurity (i.e. bronchopulmonary dysplasia, necrotizing enterocolitis, retinopathy of prematurity, and intraventricular hemorrhage) [5-7].Even though these complications are multifactorial and the smaller, more unstable babies are more likely to receive transfusions, especially bronchopulmonary dysplasia (BPD), necrotizing enterocolitis (NEC) and intraventricular hemorrhage (IVH) have been shown to be independently related with RBC transfusions [8-11].
During preparation and storage of packed RBC, changes occur in the cells called "storage lesion". Adenosine triphosphate and 2,3-diphosphoglycerate decrease, potassium increases and oxidative changes occur [11]. Considering that all the antioxidant molecules and mechanisms are decreased in premature neonates, these babies are prone to oxidative damage. Moreover, transfusionmediated iron load and especially non-transferrin bound iron may contribute to this oxidative damage and prematurity complications $[1,11,12]$.

Oxidative status can be evaluated in plasma by measuring actors of oxidative stress (free radicals and their metabolites), their products such as modified biomacromolecules, products of lipid peroxidation such as malondialdehyde (MDA), and changes in the concentrations of antioxidant enzymes and molecules [13].

The primary aim of this study was to determine the relationship between blood transfusions, ferritin levels and lipid 
peroxidation in preterm infants. Secondary aims were to monitor iron overload, find the cut-off level after which oxidative damage becomes significant and also to determine a cut-off value to start or withhold iron prophylaxis in transfused babies.

\section{Materials and Methods}

The study was designed as a cross-sectional pilot study. Twenty-three preterm infants whose gestational ages were smaller than 35 weeks were enrolled. Their demographic data and transfusion numbers are summarized on tables 1 and 2 . Restricted transfusion guidelines were used to decide the necessity of transfusions [14]. Venous blood samples were randomly taken when they were at least 20 days of age in a period free of infection according to clinical signs and laboratory test results (negative C-reactive protein and procalcitonin levels and sterile blood cultures). Serum MDA levels were measured by high performance liquid chromatography (HPLC) (Ultimate 3000, ThermoDionex, USA) with a flourescence detector. Within-run precision values were $1.8-5.5 \%$ and between-run precision values were $6.5-9 \%$ for $0.40-1.55 \mu \mathrm{mol} / \mathrm{L} \mathrm{MDA}$, according to manufacturer's claim. The lower detection limit was $0.02 \mu \mathrm{mol} / \mathrm{L}$. The method was adapted from the one applied by Hageman, et al. [15]. Serum iron and iron binding capacity were measured colorimetrically (Cobas 8000 Modular Analytics, Roche Diagnostics, Germany). Ferritin levels were measured with an immunometric test with electrochemiluminescence detection (Modular Analytics E170, Roche Diagnostics, Germany).

SPSS version 16.0 was used to analyze the results. Pearson correlation test was used for normally distributed data and a Spearman's rho for nonparametric data. The level of significance was accepted as $\mathrm{p}<0.05$. To find a cut-off level for ferritin concentration which lead to a significant MDA increase, the ferritin limit to withhold iron prophylaxis defined by World Review of Nutrition and Dietetics $(300 \mu \mathrm{g} / \mathrm{L})$ [16] was taken as a starting point and ferritin levels were compared by grouping the values with $50 \mu \mathrm{g} / \mathrm{L}$ increments. Mann-Whitney U test was used to find the level of significance among MDA levels.

This study has been approved by the ethics committee of our institution.

\section{Results}

Table 1: Demographic data of the patients.

\begin{tabular}{|c|c|}
\hline Gestational weeks (mean \pm SD) & $28.43 \pm 3.50$ \\
\hline Birth weight (mean \pm SD gr) & $1180 \pm 471$ \\
\hline \multicolumn{2}{|c|}{ Sex (\%) } \\
\hline Female & 9 \\
\hline Male & 91 \\
\hline Postnatal age & (Days) \\
\hline Mean & 53.26 \\
\hline Median & 35 \\
\hline Range & $20-190$ \\
\hline
\end{tabular}

Twenty-three preterm infants with a mean gestational age $( \pm$ SD) $28.43( \pm 3.50)$ weeks; birth weight $1180( \pm 471)$ g were included in the study. Two of the patients (\%9) were female and 21 of them were male (\%91) (Table 1). Five of the babies (group 0 - 21.7\%) were never transfused, while 10 cases (group 1 - 43.5\%) were transfused less than 5 times, 2 cases (group 2- 8.7\%) 6-10 times, and 6 cases (group $3-26.1 \%$ ) were transfused more than 10 times. The median transfusion number was 16 (range: 1-33), the patient who was transfused for 33 times was a preterm with IVH, BPD and NEC needing multiple operations and prolonged periods of high frequency oscillatory ventilation.

There was a significant difference in serum ferritin levels between transfused (median: $457 \mathrm{ng} / \mathrm{mL}$, range: 108-2717) and non-transfused (median: 203ng/mL, range: 102-268) infants $(p=0.017)$. There was a statistically significant correlation between serum ferritin and MDA levels $(\mathrm{p}<0.001 ; \mathrm{r}=0.693)$. Also, the correlation between the number of transfusions and serum ferritin levels was statistically significant $(p=0.016 ; r=0.558)$. Serum MDA levels were significantly higher in infants with serum ferritin levels $>450 \mathrm{ng} / \mathrm{mL}(\mathrm{p}<0.001)$, which coincides with the $97^{\text {th }}$ centile of normal ferritin levels designated by Obladen, et al [17]. When transfusion groups were compared, there was a statistically significant difference between ferritin levels of groups 0 and 3 which was to be expected since group 0 was never transfused - and between ferritin and MDA levels of groups 1 and 3 (Table 2). When the infants were grouped according to the number of prematurity related complications (those who had no complications, who had one complication and those who had two or more complications); transfusion numbers, serum ferritin, and MDA levels of those with two or more complications were significantly higher when compared to cases without complications $(p<0.001, p=0.001$, and $\mathrm{p}=0.019$, respectively) (Table 3).

Table 2: Comparison of ferritin and MDA* levels between transfusion groups.

\begin{tabular}{|c|c|}
\hline Transfusion Groups & Ferritin \\
\hline $0-1$ & $\mathrm{p}=0.066$ \\
\hline $0-2$ & $\mathrm{p}=0.053$ \\
\hline $0-3$ & $\mathrm{p}=0.028$ \\
\hline 2-Jan & $\mathrm{p}=0.283$ \\
\hline 3-Jan & $\mathrm{p}=0.023$ \\
\hline 3-Feb & $\mathrm{p}=0.505$ \\
\hline
\end{tabular}

*MDA: Malondialdehyde

Table 3: The relation between prematurity complications*, ferritin, $\mathrm{MDA}^{* *}$ and transfusion numbers.

\begin{tabular}{|c|c|c|c|}
\hline Complications* & Ferritin & MDA $^{* *}$ & Transfusion \\
\hline 0 - at least 1 & $\mathrm{p}=0.003$ & $\mathrm{p}=0.154$ & $\mathrm{p}<0.001$ \\
\hline 0 - at least 2 & $\mathrm{p}=0.001$ & $\mathrm{p}=0.019$ & $\mathrm{p}<0.001$ \\
\hline
\end{tabular}

${ }^{*}$ Retinopathy of prematurity, necrotizing enterocolitis, bronchopulmonary dysplasia, intraventricular hemorrhage and periventricular leukomalacia **MDA: Malondialdehyde 


\section{Discussion}

Almost all of extremely low birth weight infants receive RBC transfusion during their hospitalization period. However, after multiple transfusions serum iron and ferritin concentrations increase [4]. After transfusion, non-transferrin bound (NTB) iron and MDA increase in the plasma of preterm babies $[18,19]$. Ferritin contributes to the damage by releasing NTB iron during oxidative stress [4]. Therefore, it is necessary to monitor iron and oxidative status of these babies. In our study, we have shown that there is a statistically significant correlation between ferritin and MDA levels. Significant correlation was also present between ferritin levels of the patients and the times they were transfused.

The number of transfusions has been associated with prematurity-related complications [1-3]. In our study, the babies who suffered from at least two complications had significantly higher ferritin and MDA levels and their transfusion numbers were significantly higher. Monitoring iron status is also important for determining the time of iron prophylaxis. Elemental iron should be given to non-transfused babies to prevent anemia [4]. Even though there are many guidelines for supplemental iron, it is still not clear when to start this prophylaxis in transfused babies with high ferritin levels [16-20]. It is advised by World Review of Nutrition and Dietetics [16] that iron supplementation should be withheld until ferritin level falls below $300 \mu \mathrm{g} / \mathrm{L}$, which coincides with the 90th centile of normal levels of ferritin designated by Obladen, et al. [17]. In our study, we have shown that MDA levels raise significantly in preterm babies whose ferritin levels are above $450 \mu \mathrm{g} / \mathrm{L}$, which coincides with the 97 th centile of normal ferritin levels.

The sophisticated assays and complicated methods to detect the free iron responsible of oxidative damage bear need to find easy and reliable tests to evaluate oxidative stress - though indirectly - in babies with multiple transfusions. Taking its limitations as an acute phase reactant into consideration, in patients without acute inflammation ferritin levels can reflect lipid peroxidation as we have shown its correlation with MDA, the levels of which were higher in infants with two or more prematurity-related complications.

\section{Conclusion}

In conclusion, iron status of very low birth weight infants has to be monitored to detect iron deficiency and also transfusionrelated iron overload. It is important to use restrictive transfusion guidelines in order to protect preterm from iron overload and oxidative stress [14]. Ferritin can be used to assess the iron status of preterm, until better parameters and easier assays are found to indicate oxidative stress. As this was a pilot study consisting of 23 preterm neonates - the biggest limitation of our study further research is necessary to determine a cut-off level for ferritin to decide when to start iron prophylaxis, especially in cases with high ferritin levels. If further studies confirm these results, it would be relevant to move the ferritin cut-off limit for iron replacement initiation from $300 \mu \mathrm{g} / \mathrm{L}$ to $450 \mu \mathrm{g} / \mathrm{L}$ - where oxidative stress effects are more prominent. Instead of withholding iron prophylaxis from those who have ferritin levels $>300 \mu \mathrm{g} / \mathrm{L}$, more babies could receive iron therapy and those who would have otherwise been transfused at least one more time, might have a chance to rise their hemoglobin levels, saving themselves from a few more possible transfusion-associated side effects.

\section{References}

1. Hensch LA, Indrikovs AJ, Shattuck KE (2015) Transfusion in Extremely Low-Birth-Weight Premature Neonates: Current Practice Trends, Risks, and Early Interventions to Decrease the Need for Transfusion. Neo Reviews 16(5): e287-e296.

2. Maier RF, Sonntag J, Walka MM, Liu G, Metze BC, et al. (2000) Changing practices of red blood cell transfusions in infants with birth weights less than $1000 \mathrm{~g}$. J Pediatr 136(2): 220-224.

3. Strauss RG (2010) Anaemia of prematurity: pathophysiology and treatment. Blood Rev 24(6): 221-225.

4. Rao R, Georgieff MK (2009) Iron therapy for preterm infants. Clin Perinatol 36(1): 27-42.

5. Collard KJ, Godeck S, Holley JE, Quinn MW (2004) Pulmonary antioxidant concentrations and oxidative damage in ventilated premature babies. Arch Dis Child Fetal Neonatal Ed 89(5): F412-F416.

6. Dani C, Martelli E, Bertini G, Pezzati M, Rossetti M, et al. (2004) Effect of blood transfusions on oxidative stress in preterm infants. Arch Dis Child Fetal Neonatal Ed 89(5): F408-F411.

7. Silvers K, Gibson A, Russell J, Powers H (1998) Antioxidant activity, packed cell transfusions, and outcome in premature infants. Arch Dis Child Fetal Neonatal Ed 78(3): F214-F219.

8. Collard KJ, Godeck S, Holley JE (2005) Blood transfusion and pulmonary lipid peroxidation in ventilated premature babies. Pediatr Pulmonol 39(3): 257-261.

9. Baer VL, Lambert DK, Henry E, Snow GL, Butler A, et al. (2011) Among very-low-birth-weight neonates is red blood cell transfusion an independent risk factor for subsequently developing a severe intraventricular hemorrhage? Transfusion 51(6): 1170-1178.

10. Wan-Huen P, Bateman D, Shapiro D, Parravicini E (2014) Packed red blood cell transfusion is an independent risk factor for necrotizing enterocolitis in premature infants. J Perinatol 33(10): 858-862.

11. Collard KJ (2014) Transfusion related morbidity in premature babies: Possible mechanisms and implications for practice. World J Clin Pediatr 3(3): 19-29.

12. Lockwood WB, Leonard J, Liles S Storage (2008) monitoring, pretransfusion processing, and distribution of blood components. Technical manual (16 ${ }^{\text {th }}$ edn), Bethesda (MD): AABB, USA, pp. 289.

13. Pimkova K, Chrastinova L, Suttnar J, Stikarova J, Kotlin R, et al. (2014) Plasma levels of aminothiols, nitrite, nitrate, and malondialdehyde in myelodysplastic syndromes in the context of clinical outcomes and as a consequence of iron overload. Oxidative medicine and cellular longevity. 2014(2014): 1-10.

14. Kirpalani H, Whyte RK, Andersen C, Asztalos EV, Heddle N, et al. (2006) The Premature Infants in Need of Transfusion (PINT) study: a randomized, controlled trial of a restrictive (low) versus liberal (high) transfusion threshold for extremely low birth weight infants. J pediatr 149(3): 301-307.

15. Hageman J, Bast A, Vermeulen N (1992) Monitoring of oxidative free radical damage in vivo: analytical aspects. Chem Biol Interact 82(3): 243-293. 
16. Koletzko B, Poindexter B, Uauy R (2014) Nutritional Care of Preterm Infants. Ann Nutr Metab 110: 4- 10.

17. Obladen M, Diepold K, Maier RF (2000) Venous and arterial hematologic profiles of very low birth weight infants. Pediatrics 106(4): 707-711.

18. Hirano K, Morinobu T, Kim H, Hiroi M, Ban R, et al. (2001) Blood transfusion increases radical promoting non-transferrin bound iron in preterm infants. Arch Dis Child Fetal Neonatal Ed 84(3): F188-F193.
19. Stark MJ, Keir AK, Andersen CC (2013) Does non-transferrin bound iron contribute to transfusion related immune-modulation in preterms? Arch Dis Child Fetal Neonatal Ed 98(5): F424-F429.

20. Agostoni C, Buonocore G, Carnielli V, De Curtis M, Darmaun D, et al. (2010) Enteral nutrient supply for preterm infants: commentary from the European Society of Paediatric Gastroenterology, Hepatology and Nutrition Committee on Nutrition. J Pediatr Gastroenterol Nutr 50(1): 85-91.
Your next submission with JuniperPublishers will reach you the below assets

- Quality Editorial service

- Swift Peer Review

- Reprints availability

- E-prints Service

- Manuscript Podcast for convenient understanding

- Global attainment for your research

- Manuscript accessibility in different formats ( Pdf, E-pub, Full Text, audio)

- Unceasing customer service

Track the below URL for one-step submission http://juniperpublishers.com/online-submission.php 